\title{
Correction to: A consistently oriented basis for eigenanalysis
}

Jay Damask ${ }^{1}$ (1)

Published online: 22 June 2021

(c) Springer Nature Switzerland AG 2021

\section{Correction to: International Journal of Data Science and Analytics (2020) 10:301-319 \\ https://doi.org/10.1007/s41060-020-00227-z}

The article "A consistently oriented basis for eigenanalysis", written by Jay Damask was originally published electronically on the publisher's internet portal (currently SpringerLink) on July 02,2020 without open access. The copyright of the article changed to (C) The Author(s) 2021 and the article is licensed under a Creative Commons Attribution 4.0 International License, which permits use, sharing, adaptation, distribution and reproduction in any medium or format, as long as you give appropriate credit to the original author(s) and the source, provide a link to the Creative Commons licence, and indicate if changes were made. The images or other third party material in this article are included in the article's Creative Commons licence, unless indicated otherwise in a credit line to the material. If material is not included in the article's Creative Commons licence and your intended use is not permitted by statutory regulation or exceeds the permitted use, you will need to obtain permission directly from the copyright holder. To view a copy of this licence, visit http://creativecommons. org/licenses/by/4.0/.

The original article has been updated.

Publisher's Note Springer Nature remains neutral with regard to jurisdictional claims in published maps and institutional affiliations.

The original article can be found online at https://doi.org/10.1007/ s41060-020-00227-z.

Jay Damask

jaydamask@buell-lane-press.co

1 Buell Lane Press, New York, NY, USA 